demographic reasons.

The proposals are nevertheless welcome. On the principle that there is nothing more important to an academic institution than its freedom to determine its own affairs, any increase in the proportion of its income earned by its prime function - educating students - must be applauded. Doubts on that score should be exorcised by the recollection that, in 1981, Sir Keith (now Lord) Joseph, when Secretary of State for Education and Science, halved the level of university fees so as to make institutions more responsive to centrally imposed limits on student numbers. The reversal of that policy is an important change in the government's thinking. Belatedly, the present government has recognized that Britain is educating too small a proportion of its population to the standards that the modern world requires. Academic freedom may have been a secondary consideration, but should never be sniffed at.

The British government's specific proposal is that tuition fees should be increased from $£ 607$ a year to $£ 1,600$ a year from September 1990, meaning that British universities will derive more than 20 per cent of their income that way. At polytechnics, the proportion will exceed 25 per cent. The number $£ 1,600$ has not been plucked from the air, but chosen to be less than the average annual cost of teaching students on the cheapest courses at the most economical institutions. That means that the new funding councils will still be able decisively to affect the shape of higher education by their distribution of general support. But $£ 1,600$ is much greater than the marginal cost of teaching students (which cannot differ much from zero), giving institutions a financial incentive to take more students. Among them, there will be some grabbing of each other's business, but the key question is whether they can make broaden the market for higher education and at the same time create the diversity of higher education that Britain sadly lacks.

There is more to come. The government's consultation paper also canvasses the more complicated proposal that, from 1991, tuition fees paid from public funds will vary with the types of courses students elect to follow. At present prices, a humanities student would be worth $£ 1,600$, a mathematics student $£ 2,000$, one in science or engineering $£ 2,400$ and a medical student no less than $£ 3,200$. The intention is said to be to make the market for higher education more efficient, but this scheme would help to correct an untoward effect of the flat $£ 1,600$ fee, that expansion would be more rewarding in the arts and humanities than expansion in science and engineering, which the government, appearances apart, wishes to see prosper.

There are two snags, one practical and political, one philosophical. If the British government goes along this road and also carries through its equally rational plan for making its subventions of teaching and research explicit, the time will come when the cost of supporting teaching from the public purse will be virtually nothing at some institutions and very large at others. Then all comparisons will be invidious, and institutions whose teaching is now good, but expensive, will be cheapened - in this connection, made cheaper. The philosophical question is different. If there were a truly free market in higher education, young people would be putting themselves in the hands of institutions offering what they sought and, in return for fees of some kind, would be acquiring rights to be educated as they thought best. That is why most genuinely autonomous universities do not discriminate by cost between courses of different kinds. People must be free to choose. But not, it seems, in Britain.

\section{Political greenhouse}

Nuclear power might help combat the greenhouse effect, but only if governments are more courageous.

IndEFATIGABLE Mrs Margaret Thatcher's conversion last year to environmental causes seems to have stuck. Last week, she organized a private seminar on the subject at which other ministers and senior government officials, including heads of research councils, were given an up-todate account of where matters now stand, and were encouraged to speculate on what should happen next (see page 7). By all accounts, the meeting went a long way towards the view that the construction of nuclear power stations is essential to abate the accumulation of carbon dioxide in the atmosphere. Nobody will be surprised, but how is the goal to be accomplished?

Chernobyl notwithstanding, there is now an ample historical record to show that nuclear power stations can be built and operated safely. The experience of Western Europe in this regard is quite remarkable. There are also incidents, such as that at the Three Mile Island power staion in Pennsylvania, which show that nuclear accidents need not be catastrophic. But most people, for reasons that are entirely understandable, read recent experience differently. Why cannot what happened near Kiev three years ago happen anywhere? And what is to be done with waste?

If the world is the rational place that we pretend, there is no reason why these anxieties should not be laid to rest. The most urgent need is assurance that human errors of the kind responsible for most known accidents will not recur, which argues for an unprecedented degree of openness about the management of nuclear plants. Will governments comply? Waste disposal, which should be a lesser anxiety, has been allowed by all governments' pusillanimity to grow into a monster. The British government has been especially wayward in its careful calculations of the political disadvatages of particular disposal sites. Will it and others now be more courageous?

The diagnosis is correct that nuclear power (together with energy efficiency) could help to avoid or postpone the greenhouse effect. But only governments can now create the climate of glasnost in which these benefits can be won. That will not be an easy task.

NATURE $\cdot$ VOL $339 \cdot 4$ MAY 1989 